\title{
The Impacts of Asian Currency Crisis on International Portfolio Diversification
}

\author{
Tak-Kee Hui $^{*}{ }^{1}$, Rudy Kurniawan ${ }^{1}$ and Hsuan-Yi Cheng ${ }^{2}$ \\ ${ }^{l}$ NUS Business School, Singapore \\ ${ }^{2}$ National Taichung Institute of Technology, Taiwan
}

\begin{abstract}
This paper is to investigate the benefits of including bonds and stocks markets in the optimal portfolio using the classical model. Three types of investments: stocks alone, bonds alone, and a mix of stocks and bonds are considered. Efficient frontier is constructed for each type of investment. This study is also to include international diversification choices before and after the recent Asian currency crisis. It has been shown that the risk of investment can be reduced by diversification across countries. For both before and after Asian currency crisis, our results show that investing in the bond markets alone will provide substantial return and optimal risk reduction for investors who are risk averse. However, the combination of stocks and bonds will provide a better mix giving a highest return per unit risk. After the Asian currency crisis, the bond markets selected are shifted from North America markets to Oceania markets and France market. This analysis provides a comprehensive study for Singaporean investors but the research can be repeated from a different perspective such as Japan and US point of view.
\end{abstract}

\section{INTRODUCTION}

Global financial markets have become more integrated over the last decade due to the liberalization of financial sectors in increasing number of countries. Researches in the past have found that investing across countries can result in more benefits in terms of reduction of risks, as compared to investing in different industries within the same country (Grubel [1]; Lessard [2]; Adas and Dumas [3]; Li, Sarkar and Wang [4]; Hui [5] Fletcher and Marshall [6a]; Driessen and Laeven [7]). Studies in Modern Portfolio Theory (classical approach), pioneered by Markowitz [8], suggest that the risk of holding different assets can be reduced by diversification and the degree of diversification depends on the correlations among the assets.

Asian currency crisis has brought tremendous effects and changes to the financial landscapes in the region. It officially originated from the meltdown of Thai baht in July 1997 and the effects spread across to most of the South-East Asian countries. The values of most currencies had declined to unbearable level. Property market slumped. Some economies had basically become stagnant. Social problems escalated. Asian stock values dropped dramatically and eventually the impacts were felt by other countries around the world, even by global economic power houses.

With lower expected return and higher return volatility (or uncertainty) of international financial assets, like stocks and bonds, after the Asian currency crisis, international portfolio diversification and management become critical issues. International investors hope to diversify their investments at such bad times because if one market is not performing well, it can be compensated by the positive performances from other markets. Hence, the presence of potential benefits of international diversification becomes an important factor for global investment strategy during global economic recession.

*Address correspondence to this author at the NUS Business School, Singapore; E-mail: bizhuitk@nus.edu.sg
However, many recent researches have found that there is substantial increase in correlations of stock markets and other financial assets during the global downturns. Meric and Meric [9] compared the co-movements of European equity markets before and after the 1987 crash and concluded that significant increase in market correlations were observed and hence, reduction in benefits of international diversification. Campbell, Koedijk and Kofman [10] further reconfirmed the increase in correlation coefficient among international stock markets during bearish times.

The objective of this study is to investigate the effects of Asian currency crisis on the construction on the portfolios of stock markets only, bond markets only and both stock and bond markets from Singapore perspective. Comparison is made for different portfolio holdings before and after the Asian currency crisis. In section 2 the literature review of the benefits of international portfolio diversification are discussed. The description of the data set and methodology will be given in Section 3. Empirical results and conclusion will then be presented in the last two sections.

\section{LITERATURE REVIEW}

\section{Potential Benefits from International Diversifications}

The work of Markowitz [8] brought about tremendous change in the financial sector, particularly in the asset management and portfolio selection. Markowitz [8] specified a mean-variance model for calculating optimal portfolios, which is well-known as the Classical Method of MeanVariance optimization. The theoretical models developed by Markowitz [8] provided concrete proof and positive explanation that risk diversification can be achieved. The degree of diversification depends on the correlations of returns among the assets held, the lower the correlation among the assets in a portfolio, the greater risk diversification can be achieved and vice versa.

Grubel [1], Levy and Sarnat [11], Lessard [2] and Grubel and Fadner [12] extended the basic mean-variance principle of Markowitz to the international portfolio diversification context and examined the potential gains by investing differ- 
ent countries. They found that the multinational diversification was superior than investing in single country. Errunza [13], who examined the increase in returns due to investment in less developed countries, concluded that portfolios of less developed countries' stock indices dominated the US stock index. Madura [14] argued that even though investors were aware of the potential benefits of international diversification, however, many investment activities were hindered by market imperfections, such as capital control and lack of information. Errunza and Padmanabhan [15], who extended the study on 10 emerging markets from the period between 1976 and 1984, also discovered similar benefits.

On the other hand, Bailey and Stulz [16] took a different unique approach of using the daily return for the Pacific Basin markets to estimate the benefits from international diversification for the US investors' perspective. Their results showed that the benefits of international diversification in the Pacific Basin markets were substantial but also could be easily overestimated when daily returns were used in the computation.

Most of the research on international diversification in the 1980s focused on the US investors' perspective, ignoring the perspectives of other investors from different countries around the world. Soenen and Lindvall [17] investigated the international diversification benefits of equity portfolio and currency hedging benefits from the US and other six major countries' point of views, namely Canada, France, Germany, Japan, Switzerland and U.K. from 1973-1989. The results also suggested that international diversification reduced risk but not necessarily increased returns. The study confirmed the presence of risk reduction benefits of international equity portfolio as compared to solely domestic portfolio for all perspectives studied except for Canadians.

However, as industry groups have become more developed and clearly outlined, many researchers have concentrated on studies that compare the benefits of country diversification and industry diversification. Heston and Rouwenhorst [18] compared the industry and country effects in international diversification on European countries. Rouwenhorst [19] found that similar trend exists over the past few years where more integration occurs among Western European countries. Only a small percentage of the benefits from international diversification were attributed by the industry and currency diversification. He concluded that industry effects were very small and therefore, country diversification was a more effective tool for achieving international diversification benefits.

Clarke and Tullis [20] also reconfirmed that in order to enhance investment returns, the portfolio should include about 20\%-30\% in foreign equity. Schirripa and Tecotzky [21] found that the strategy of pooling investors with diverse risk-reward profiles in a fund improved the expected returns that each investor could have achieved with a limited number of stocks. Vladimir [22] suggested that by adding only a few stocks to a non-diversified portfolio could produce significant risk reduction benefits.

A different approach to studying this issue was taken by Gilmore and McManus [6b], who investigated the short-term and long-term correlations between the US and three Central European countries (Czech Republic, Poland and Hungary).
They found that there was a constantly low correlation among the four markets and hence, the potential benefit of diversification by the American into those countries existed for short- and long-term investors. Hui [5] used factor analysis approach to study the potential benefit of diversification by investing in US and Asia-Pacific markets from the Singaporean perspective and found that risk can also be diversified in the well developed market such as Australia and not necessary US market.

\section{The Importance of Bond on International Diversification}

Considering other assets than stocks in portfolio selection and management, international bond markets have been found to be crucial in improving the benefits of international diversification. The higher degree of transparency in international bond markets in recent years has also allowed researchers to investigate bonds' contribution to international diversification. Grauer and Hakansson [23] studied the importance of including non-US assets to enhance the portfolio returns. The study was done on 14 non-US equity and government bonds categories. One of the major findings suggested that there was a remarkable gain for including nonUS asset categories in the portfolio, especially for highly risk-averse investment strategies.

The difference in the risk-return characteristics of stocks and bonds has contributed to the attractiveness of international portfolio diversification. Turner and Hensel [24] analyzed the presence of significant difference between stock and bond returns from each of the six countries for stocks and five countries for bonds. The results showed that sample stock or bond returns of each country were not significant different from the other country. However, the variances of the returns among the countries were substantially large, rendering some difficulties to detect the difference in the population means.

Odier and Solnik [25] reemphasized the importance of both bonds and stocks as components in global asset allocation. They found that foreign assets, especially bonds, remained attractive even if the correlation between markets was increasing slightly, because economic policy was relatively independent of the state of the national economy. This study did not just focus from the US investor's perspective (by converting returns in US dollar) but also from German, Japanese and British perspectives. Findings also suggested that correlations of both equity and bond markets were larger between countries with strong economic and monetary relationship, especially the trade bloc countries.

Eun and Resnick [26] have done a similar study that compared the international diversification of bond and stock markets, using Japan and US perspectives. The study focused on 7 developed markets. They concluded that potential gains from international diversification, as opposed to purely domestic, were much greater for US investors than for Japanese investors. Their study also showed that for US investors, the international bond diversification (with exchange risk hedging) offered superior risk-return trade-off than the international stock diversification (with or without exchange risk hedging).

Jones and Wilson [27] showed new estimates of bond real returns, by taking into consideration of inflation, over a long period of time, from December 1856 to December 
1995. The study also compared bond real returns with that of stocks and concluded that the performance of bond returns was remarkably high in recent years. However, given regardless of the seemingly strong bond performance, the study suggested that asset allocation decisions had to be considered cautiously. Bonds were considered superior for risk reduction and diversification purpose but not for increasing returns.

\section{The Currency Component on Portfolio Management and Diversification}

Due the fact that many countries had adopted a fixed exchange rate system before 1980s, the favorable prior results from international diversification were suspected to be inconsistent when tested on countries with flexible exchange rate systems. The gain or loss in currency movement had, therefore, to be considered to obtain total return from investing abroad. Solnik [28] studied diversification by analyzing actual stocks of foreign markets during the fixed exchange rate regime from the period of 1960 to 1971. the results showed that international diversification was attractive regardless of the investor's home country. Saunders and Woodward [29], and Biger [30] analyzed the systematic risk of foreign exchange by deriving efficient sets on international portfolios from different country's viewpoints and found that the exchange rate risk was not as significant as would be expected.

Eun and Resnick [31] showed that despite the exchange rate volatility and the unavailability of perfect exchange rate hedging, there were still substantial gains from international diversification. Raymond and Weil [32] also concluded that the benefits of international diversification still existed, however, were smaller than they expected. Jorion [33] examined monthly stock returns of 287 US multinationals from 1971 to 1987 and found that the impact of nominal exchange rate changes was statistically insignificant. Jorion [34] aimed to understand the trend of increasing overlay managers who were employed to manage currency separately from the foreign assets holdings. The results showed that when the underlying assets and currencies were more closely integrated and correlated, under-performance of returns was observed. However, he argued that such negative performance could be minimized as currency return was quite predictable.

Rustem [35] argued that the traditional mean-variance formulation with overall risk that had a multiplicative effect from the return risk and the currency risk. Such currency risk could be perceived as past forecast errors and hence, might be ignored. Tang [36] investigated the impact of investment horizon on currency portfolio diversification and found that the correlation between currency returns increased as the investment horizon increased, which suggested that the long run benefits of international diversification would be reduced. In fact, Tang [37] also examined the issue on naïve portfolio and found that a portfolio size of 20 was required to eliminate $95 \%$ of the diversifiable risk on average.

Chow, Lee and Solt [38] examined the effects of real exchange rate on both stocks and bonds returns. They found that bond returns were more responsive to both short and long run changes in real exchange rates while stock returns were responsive only to long run changes. Baz et al. [39] constructed mean-variance optimal currency portfolios of
German deutschemark, Japanese Yen, British pound and Swiss franc. The study has found that optimal portfolio investment in these currencies with US dollar as risk-free asset generated excess return of $2.79 \%$ per year from November 1989 to June 1999.

\section{DATA AND METHODOLOGY}

The data used in this study consist of the monthly returns from Morgan Stanley Capital International (MSCI) national stock indices with dividend yield for 17 major stock markets and 15 government bond indices plus average annual coupon rate beginning from June 1990 to May 2002 which are obtained from NUS Datstream. The stock indices are selected from markets in North America, Europe and Asia-Pacific. The bond indices are selected from the same countries except Hong Kong and Singapore as the bond indices from these two markets are still at the early stage as compared with the other selected markets and so the data are not extensively available.

This study will be on the investments from the Singapore perspective. Our findings will focus on the effects of the Asian currency crisis on international diversification and so the full sample dataset are divided into two sets, namely, before crisis and after crisis. The currency crisis starts in July 1997. Hence, for the before crisis data, it will be from June 1990 to June 1997 and for the after crisis it will be from July 1997 to May 2002. Three efficient frontiers (stock alone, bond alone and the mix of stock and bond) are constructed based on the classical approach mentioned above. For comparison purpose, the efficient frontiers based on the full set are also constructed.

In order to construct the classical mean-variance efficiency, two important estimates are required, namely the expected return vector and the variance-covariance matrix and they are estimated by the sample mean vector and sample variance-covariance matrix.

Mathematically, the portfolio optimization problem can be expressed as follows:

$\operatorname{minimize} \sigma_{p}^{2}=\underset{\sim}{X} V \underset{\sim}{X}$

subject to the following constraints:

$$
\begin{aligned}
& \underset{\sim}{X^{\prime}} \underset{\sim}{R}=R_{s} \\
& \underset{\sim}{X^{\prime}} \underset{1}{\sim}=1 \quad \mathrm{X}_{i} \geq 0 \text { fample variance-covariance matrix, } i=1,2, \ldots, \text { where } \\
& \underset{\sim}{X}=\text { vector of investment proportion, } \\
& \underset{\sim}{R}=\text { sample vector of returns, } \\
& \underset{1}{\underline{1}}=\text { unit vector, } \\
& R_{S}=\text { expected return of portfolio, } \\
& X_{i}=\text { proportion of total portfolio invested in country } i
\end{aligned}
$$

By setting different values of $R_{S}$ in equation (2), we can obtain the respective minimum variance, in equation (1) and proportions of fund to be invested in each asset. The equations above are solved using the quadratic programming in Excel Solver. Graph of efficient frontier is thereupon plotted 


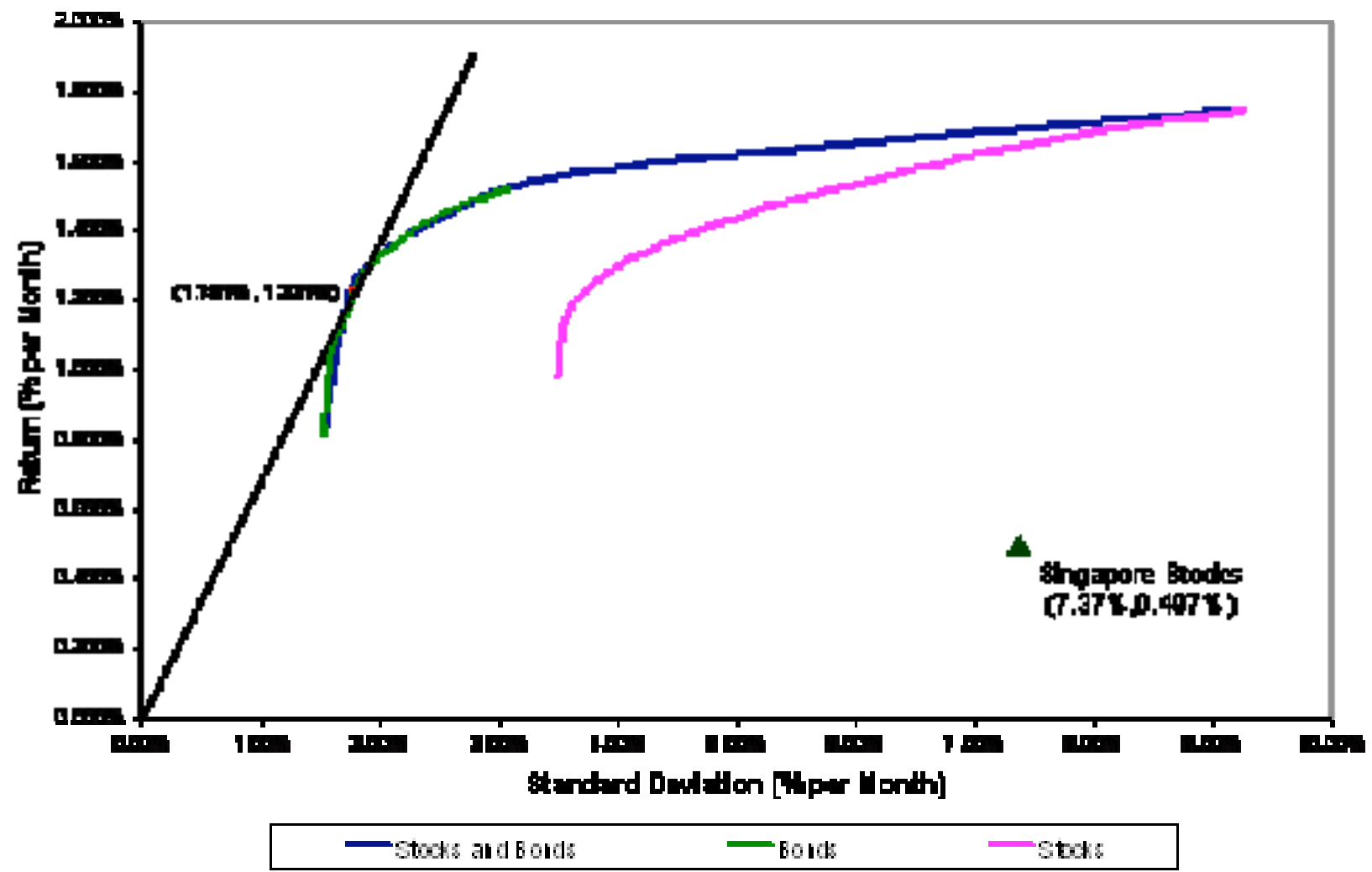

Fig. (1). Efficient frontier for stocks, bonds and both stocks\&bonds, period June 1990-May 2002 (monthly return).

using several pairs of $R_{S}$ and the corresponding portfolio's standard deviation.

\section{EMPIRICAL RESULTS}

Based on the classical approach and the full set of data, three efficient frontiers, namely, bond, stock and mixed markets, are plotted from the Fig. (1) above, it can be observed that Singapore stock market is well below all frontiers. Hence, the benefits of diversifying into stock markets alone, bond markets alone and the mixed markets are obvious and they further support the results of the past research. The results also show that investing in the bond markets alone will provide substantial return and optimal risk reduction for those investors who are risk adverse. However, the combination of stock and bond markets will provide a better mix.

Table 1 below shows the proportions of fund that are invested in different international stock markets in order to yield the highest return per unit risk. In this case, it is 3.292. Note that the highest percentage in the portfolio goes to Australia (55.093\%) and Canada (24.328\%). It is surprised that the portfolio doesn't include the US stock market as well as the Asia stock markets. The other components go to the Europe markets. As for the bond alone, the highest return per unit risk is 6.788 which indicates that the bond market may be the better alternative for better risk reduction and highest return. Again, it is noted that more weights are allocated to Canada bond market (44.026\%) and the France bond market $(33.315 \%)$. Japan is the only Asia bond market (3.677\%) included in the portfolio. Australia and New Zealand bond markets take up $16.327 \%$.
For the mixed market (both stock and bond markets), the highest return per unit risk is 6.821 which is superior than investing in the bond market alone. However, the weightage in the portfolio still favors the bond markets more than the stock markets. The only stock market included in the portfolio is Sweden stock market. As seen in the table, a total of 98.1\% goes to the bond markets which include Australia, Japan, New Zealand, France, Italy and Canada.

The efficient frontiers based on the dataset before and after Asian financial crisis are given in Fig. (2). Both efficient frontiers (before and after financial crisis) are well above the respective Singapore stock market. These results support not just the benefit of diversifying into different markets but also show that regardless of the currency crisis, the benefit is still very obvious and it is only a matter of the degree of risk reduction and return achieved. It is also noted that the efficient frontier based on those before crisis data has higher return per unit risk than those based on after crisis data. This shows that the Asian currency crisis has a significant impact on the optimal portfolio management.

Table 2 shows the proportions of fund invested in different markets before the Asian currency crisis. For the stock market alone, the highest return per unit risk is 5.759 with most of the funding invested in the US stock market (51.127\%) and Hong Kong is the only market selected in Asia with $2.953 \%$. As for the bond market, the return per unit risk is 10.906 and it is almost doubled those invested in the stock market alone. Most of the funding is in the Canadian bond market with $44.145 \%$. However, the mixed markets seem to be the best with 11.015 as return per unit 
Table 1. Investment Portfolio (Based on the Full Dataset)

\begin{tabular}{|c|c|c|c|}
\hline Weightage & Stock Market Alone & Bond Market Alone & Mixed Markets \\
\hline Australia (S) & 55.093 & & \\
\hline United Kingdom (S) & 0.218 & & \\
\hline Netherlands (S) & 17.178 & & \\
\hline Belgium (S) & 0.377 & & \\
\hline Sweden (S) & 2.806 & & 1.907 \\
\hline \multicolumn{4}{|l|}{ United States (S) } \\
\hline Canada (S) & 24.328 & & \\
\hline Australia (B) & & 4.620 & 5.786 \\
\hline Japan (B) & & 3.677 & 3.503 \\
\hline New Zealand(B) & & 11.707 & 11.307 \\
\hline France (B) & & 33.315 & 32.188 \\
\hline Italy (B) & & 2.655 & 0.906 \\
\hline \multicolumn{4}{|l|}{ United States (B) } \\
\hline Canada (B) & & 44.026 & 44.404 \\
\hline Portfolio Return & 1.241 & 1.215 & 1.221 \\
\hline Portfolio Risk & 0.377 & 0.179 & 0.179 \\
\hline Return per unit risk & 3.292 & 6.788 & 6.821 \\
\hline
\end{tabular}

*All numbers in the table are in percentage.

risk with only $2.008 \%$ in US stock market but $44.523 \%$ in Canadian bond market.
The proportions of fund invested in different markets after Asian currency crisis are shown in Table 3. It is noted

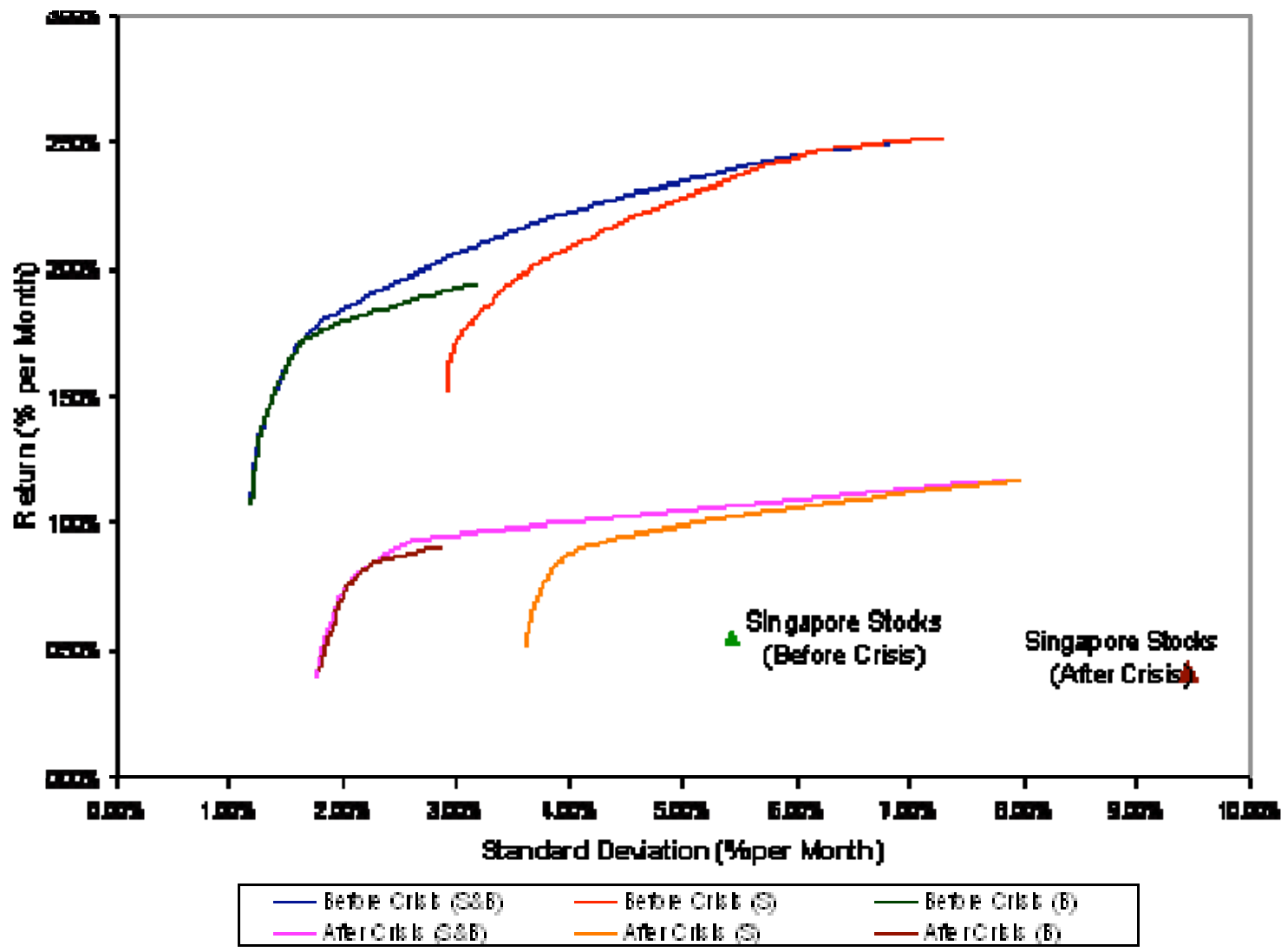

Fig. (2). Efficient frontier for stocks, bonds and both stocks\&bonds, before crisis $v s$ after crisis (monthly return). 
Table 2. Investment Portfolio (Before Asian Financial Crisis)

\begin{tabular}{|c|c|c|c|}
\hline Weightage & Stock Market Alone & Bond Market Alone & Mixed Markets \\
\hline Australia (S) & & & \\
\hline Hong Kong (S) & 2.953 & & \\
\hline United Kingdom (S) & & & \\
\hline Netherlands (S) & 21.230 & & \\
\hline Belgium (S) & & & \\
\hline Sweden (S) & 1.331 & & 0.023 \\
\hline United States (S) & 51.127 & & 2.008 \\
\hline Canada (S) & 23.360 & & \\
\hline Australia (B) & & & \\
\hline Japan (B) & & 8.094 & 7.842 \\
\hline New Zealand(B) & & 5.011 & 4.752 \\
\hline France (B) & & 16.182 & 15.907 \\
\hline Italy (B) & & 12.962 & 13.254 \\
\hline Sweden (B) & & 0.743 & 0.670 \\
\hline United States (B) & & 12.863 & 11.020 \\
\hline Canada (B) & & 44.145 & 44.523 \\
\hline Portfolio Return & 1.774 & 1.505 & 1.520 \\
\hline Portfolio Risk & 0.308 & 0.138 & 0.138 \\
\hline Return per unit risk & 5.759 & 10.906 & 11.015 \\
\hline
\end{tabular}

*All numbers in the table are in percentage.

that the return per unit based on the stock markets alone, bond markets alone as well as the mixed markets are dropped drastically. This supports what we have observed in Fig. (2). For the stock market alone, it drops more than $61.8 \%$ and the Australia stock market takes up $81.316 \%$. Surprisingly, the US stock market is not selected which is different from the previous case where US plays a major role in the portfolio. As for the bond market alone, the return per unit risk drops from 10.906 to 3.717 which is about $65.9 \%$ decreased. Canadian bond market only picks up $9.039 \%$ instead of $44.145 \%$ (before currency crisis) and the funding is now shifted to France bond market with $51.792 \%$. Similar results are observed in the mixed markets. The return per unit risk drops $65.6 \%$ with high percentage funding invested in France bond market (43.236\%). Australia and Italy are the only two stock markets included in the portfolio and they pick up $5.357 \%$.

In summary, the study supports the benefit of diversifying funding across countries as in the past research. The results above also show that the Asian currency crisis has a significant impact on the proportion of investment portfolio constructed. It is more obvious in terms of the return per unit risk where it drops more than $65 \%$ in all cases. However, the mixed markets still provide a better choice for investment.

\section{CONCLUSION}

This study has not just confirmed the past research findings that the risk reduction can be achieved by investing in different stock markets. In fact, the benefit in terms of return and risk can be further improved by including the bond mar- kets. As seen in the Table 1, investing in the bond markets have a better return per unit risk than investing in the stock markets. It increases about $51.5 \%$. The return is the highest if investing in the mix markets.

From Singapore perspective, the impact of the Asian currency Crisis is felt intensely by the Singapore investors. As seen in both Tables $\mathbf{2}$ and $\mathbf{3}$, the portfolio constructed does not include the financial assets, such as stocks and bonds from the South-East Asian countries. Such negative impact is attributed to the downward pressure of the Singapore dollar amidst the regional economic and political instability. However, bond markets still dominate the international portfolio selection and in fact the risk increases tremendously after the crisis.

As seen in the optimal portfolio based on the mixed markets, Hong Kong is the only market in Asia to be included before the Asian currency crisis and the Australia stock market is the only market included after the Asian financial crisis. Most of the funding goes to the bond markets. Before the crisis, about $55.543 \%$ are invested in the North America bond markets (including both US and Canada) and the funding is shifted to Oceania bond markets (Australia and New Zealand) and France market and it is only $11.653 \%$ remained in the Canadian bond market.

The results of this study suggest that if Singaporean investors or portfolio managers want to select relatively large and well-developed stock and bond markets for risk reduction, then the bond markets are the best choice than the stock markets whether it is before or after financial crisis. The se- 
Table 3. Investment Portfolio (After Asian Financial Crisis)

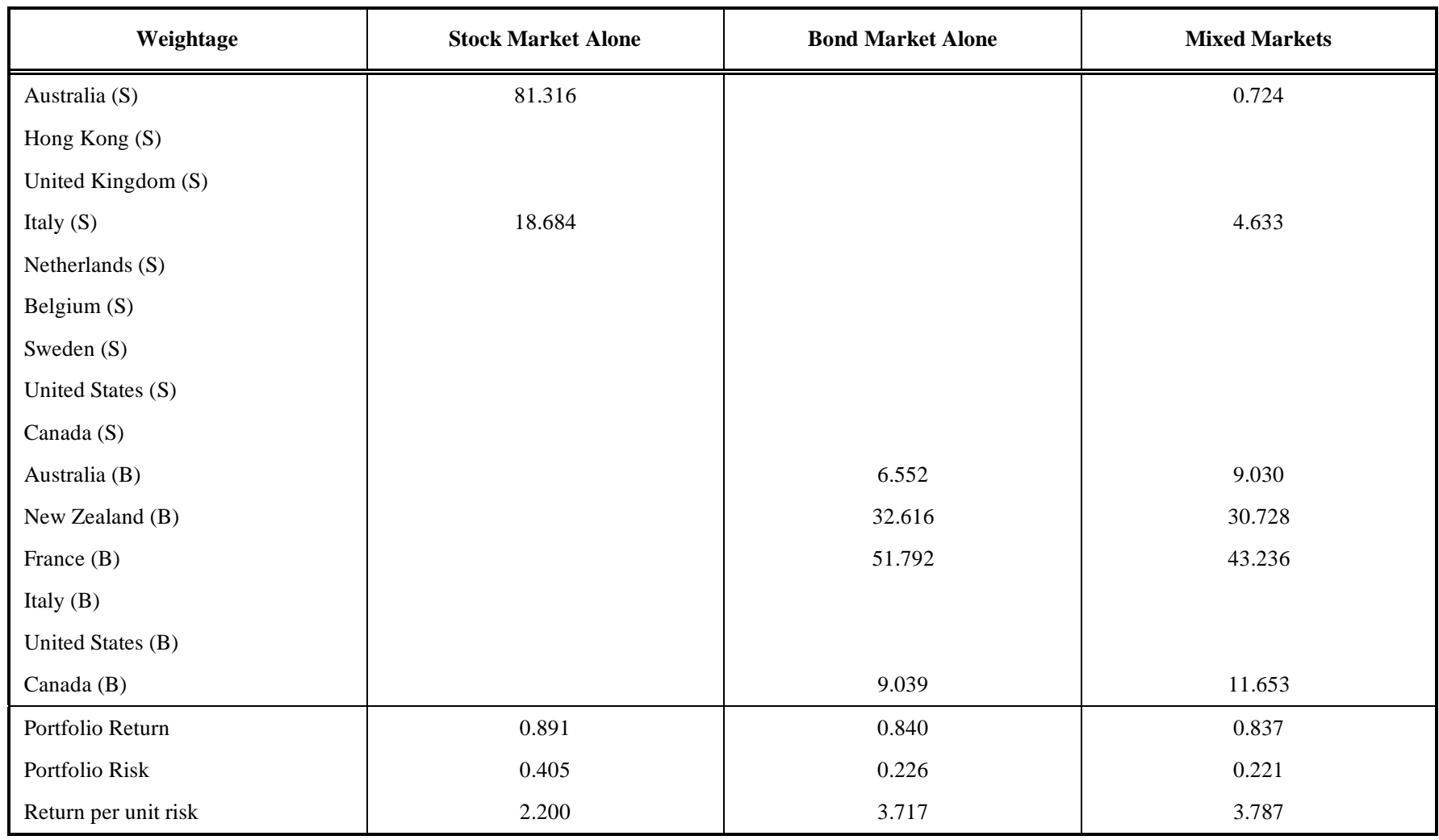

*All numbers in the table are in percentage.

lected bond markets may not be necessary from North America markets but from Oceania markets and European markets. The idea of this study can in fact be repeated from a different perspective such as Japan or US point of view.

\section{REFERENCES}

[1] Grubel HG. Internationally diversified portfolio: welfare gains and capital flows. Am Econ Rev 1968; 1299-1314.

[2] Lessard D. International Portfolio Diversification: A Multivariate Analysis for a Group of Latin American Countries. J Finance 1973; 28: 619-633.

[3] Adas M, Dumas B. International portfolio choice and corporation finance: a synthesis. J Finance 1983; 38: 925-984.

[4] Li K, Sarkar A, Wang Z. Diversification Benefits of Emerging Markets subject to Portfolio constraints. J Empirical Finance 2003; 10: $57-80$

[5] Hui TK. Portfolio diversification: a factor analysis approach. Appl Finan Econ 2005; 15: 821-834.

[6a] Fletcher J, Marshall A. An empirical examination of the benefits of international diversification. J Int Finan Markets Inst Money 2005; 15: 455-468.

[6b] Gilmore CG, McManus GM. International portfolio diversification: US and Central European equity markets. Emerg Markets Rev 2002; 68-83.

[7] Driessen J, Laeven L. International Portfolio Diversification benefits: Cross-country evidence from a local perspective. J Banking Finance 2007; 31: 1693-1712.

[8] Markowitz H. Portfolio Selection. J Finance 1952; 7: 77-91.

[9] Meric I, Meric G. Co-Movements of European Equity Markets Before and After the 1987 Crash. Multinat Finance J 1997; 1: 137152.

[10] Campbell R, Koedijk K, Kofman P. Increased correlation in bear markets. Financial Analysts Journal 2002; 58: 87-94.

[11] Levy H, Sarnat M. International Diversification of Investment Portfolios. Am Econ Rev 1970; 668-675.

[12] Grubel HG, Fadner K. The interdependence of international equity markets. J Finance 1971; 26: 89-94.
[13] Errunza VR. Gains from portfolio diversification into less developed countries' securities. J Int Bus Stud 1997; 8: 83-99.

[14] Madura J. International Portfolio Construction. J Bus Res 1985; 8795.

[15] Eurrunza VR, Padmanabhan P. Further evidence on the benefits of portfolio investments in emerging markets. Financial Analysts Journal 1998; 44: 76-78.

[16] Bailey W, Stulz RM. Benefits of international diversification: the case of pacific basin stock markets. J Portfolio Manag 1990; 16: 57-61.

[17] Soenen LA, Lindvall JR. Benefits from diversification and currency hedging of international equity investments: different countries' viewpoints. Global Finance J 1992; 3: 145-158.

[18] Heston SL, Rouwenhorst KG. Does industrial structure explain the benefits of international diversification? J Finan Econ 1994; 36: 3 27.

[19] Rouwenhorst KG. European equity markets and the EMU. Financial Analysts Journal 1999; 55: 57-64.

[20] Clarke RG, Tullis RM. How much international exposure advantageous in a domestic portfolio? J Portfolio Manage 1999; 25: 33-44.

[21] Schirripa F, Tecotzky ND. An optimal frontier. J Portfolio Manage 2000; 26: 29-40.

[22] Vladimir de Vassal. Risk diversification benefits of multiple-stock portfolios. J Portfolio Manag 2001; 27: 32-39.

[23] Grauer RR, Hakansson NH. Gains from international diversification: 1968-85 returns on portfolios of stocks and bonds. J Finance 1987; 42: 721-739.

[24] Turner AL, Hensel CR. Were the returns from stocks and bonds of different countries really different in the 1980s? Manag Sci 1993; 39: 835-844.

[25] Odier P, Solnik B. Lessons for International Asset Allocation. Financial Analysts Journal 1993; 49: 63-77.

[26] Eun CS, Resnick BG. International diversification of investment portfolios: U.S. and Japanese perspectives. Manag Sci 1994; 40: 40-161.

[27] Jones CP, Wilson JW. Expectations about Real Returns. J Portfolio Manag 1999; 25: 45-52.

[28] Solnik BH. Why not diversify Internationally? Financial Analyst Journal 1974; 30: 48-54. 
[29] Saunders A, Woodward RS. Gains from International Portfolio Diversification: UK Evidence 1971-1975, J Bus Finan Account 1977; 299-309.

[30] Biger N. Exchange rate implications of international portfolio diversification. J Int Bus Stud1979; 64-74.

[31] Eun CS, Resnick BG. Currency factor in international portfolio diversification. columbia. J World Bus 1985; 45-53.

[32] Raymond AJ, Weil G. Diversification benefits and exchange rate changes. J Bus Finan Account 1989; 16: 455-466.

[33] Jorion P. The Exchange Rate Exposure of US Multinationals. J Business 1990; 63: 331-345.
[34] Jorion P. Mean/variance analysis of currency overlays. Financial Analysts Journal 1994; 50: 48-56.

[35] Rustem B. Computing optimal multi-currency mean-variance Portfolios. J Econ Dynam Control 1995; 19: 901-908.

[36] Tang GYN. Impact of investment horizon on currency portfolio diversification. Int Bus Rev 1996; 5: 99-116.

[37] Tang GYN. How efficient is naïve Portfolio Diversification? An educational Note. Omega 2004; 32: 155-160.

[38] Chow E H, Lee WY, Solt ME. The exchange-rate risk exposure of asset returns. J Bus 1997; 70: 105-123.

[39] Baz J, Breedon F, Naik V, Peress J. Optimal portfolios of foreign currencies. J Portfolio Manag 2001; 27: 102-111. 